\title{
Modern Digital Device Systems Supporting the Instruction of Digital Natives
}

\author{
György MOLNÁR \\ Budapest University of Technology and Economics, Hungary \\ e-mail: molnargy@eik.bme.hu
}

\begin{abstract}
While in our accelerated world everything seems to change, basic values are here to stay. I believe one such aspect is education and training. Although our educational system is built on a relatively permanent basis, instructional methodology on the whole has undergone substantial changes despite that all of the educational system has preserved its role in transmitting, presenting, and preserving knowledge. Since in our fast $21^{\text {st }}$-century world myriads of facts and fake or questionable information is available, students require new knowledge along with new and perhaps different answers. We believe that education, due to its ability to provide scientifically sound answers to the respective challenges, is vital today. Recent paradigm shifts have led to fundamental alterations in the form of information and knowledge acquisition supported by modern, state-ofthe-art ICT-based methodological solutions and learning environments. The study focuses on the theoretical and practical aspects of such learning support schemes or solutions.
\end{abstract}

Keywords: digital learning environments, ICT-based methodology, digital learning solutions, digital natives

\section{Introduction}

The actual participants of our educational system face several challenges and changes resulting in radical alterations of the methods of knowledge acquisition and processing. The educational and didactic principles and tasks supporting learning-centred and constructivist teaching take new forms in the current digital environments. The $21^{\text {st }}$ century is the age of experience pedagogy, which - bolstered by international research results and the respective practice - is gradually applied in domestic educational contexts too. Relevant international (Hülber, 2017) and domestic (Bodnár-Sass, 2014) research results substantiate the legitimacy and prove the efficiency, and in some cases the effectiveness, of that method. In today's world permeated with digital culture, educational institutions 
have to be prepared to provide modern, ICT-supported learning environments (Szúts, 2014; Molnár-Szúts, 2016). Consequently, in order to accommodate the needs and the demands of the upcoming generation, the framework system of the digital school should be developed (Prensky, 2001, 2012). Such aspirations are served and supported by the EU recommendations prepared by the experts of the scientific and knowledge centre of the European Commission, the Joint Research Centre (JRC). As a result of efforts to prepare framework systems for describing the digital competence of European people, the DigCompOrg and the DigCompEdu framework systems were issued in 2017, addressing the needs of educational institutions and instructors respectively (Learning \& Skills, 2017). Currently, with an eye to domestic specifications, these solutions are being adapted in Hungary.

\section{Selection of Popular Web 2.0 Applications}

Below, I will describe the main functions of a few frequently used and popular web 2.0-based interactive programs and applications that can be successfully integrated into the current teaching and learning processes.

\section{Plickers (https://www.plickers.com)}

Plickers provides a voting system via a mobile telephone or any smart device, including a camera operated by the teacher.

The use of Plickers greatly simplifies immediate evaluation. Teachers only need a mobile device, and students use a printed white sheet identifiable by a pictogram. When answering the teacher's questions, they raise the sheet and turn it towards him/her. Depending on the given answer, the pictogram can be turned in 4 directions (A, B, C, or D). One disadvantage is that it can only be used in case of multiple choice tests.

The temporary break in connection and the resulting inability to reach the Internet is a frequent problem in schools. The AR-based Plickers offers a solution via turning the classroom into an interactive location without students using their phones or requiring Internet connection.

In order to test the system, it is enough to register at the website, and after establishing one or more classes and potentially entering the names of students the application can be downloaded onto a smart phone. Having printed the answer sheets, the system is ready for testing. It is easy to use as the teacher asks a question with four potential answer options. In response, each student raises their answer card turned to display the letter representing the appropriate answer. After starting the application, a camera records the answers and the teacher can 
see each student's replies. At the same time, the results are available along with their distribution at the Plickers website. Thus, the respective answers can be projected for the whole class to see, and exporting options are available as well.

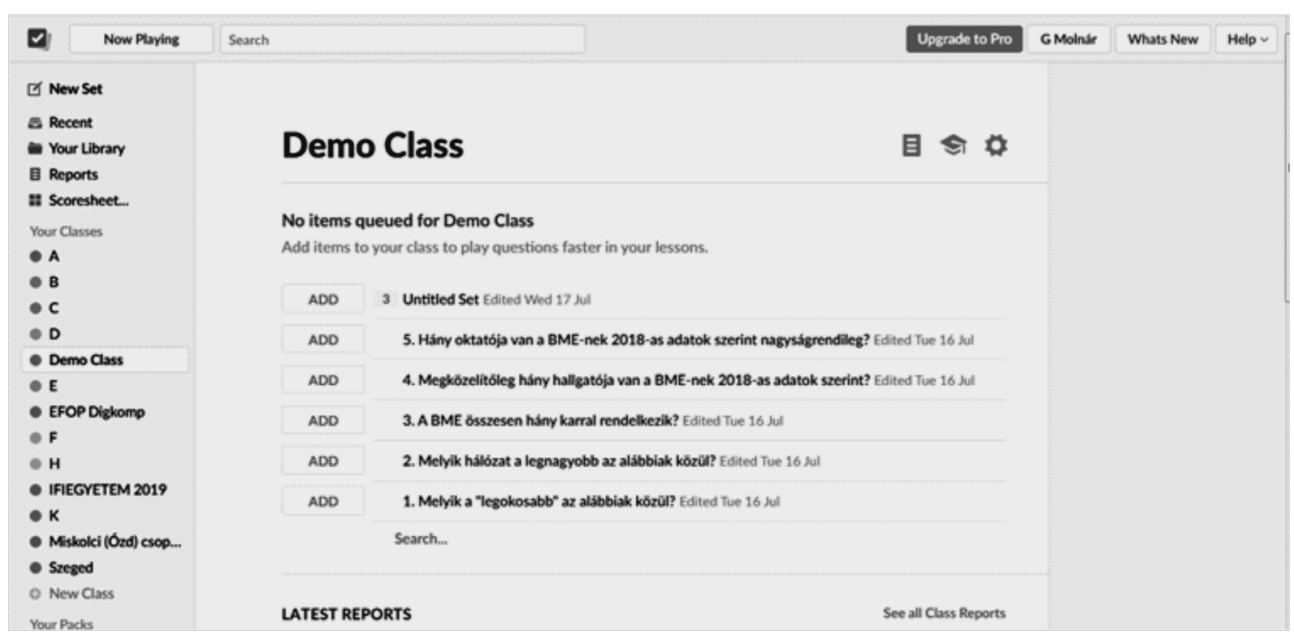

Source: author's screenshot

Figure 1. The user surface of Plickers after entry

\section{Menti (https://www.mentimeter.com; https://www.menti.com)}

Mentimeter is a presentation software enabling students to answer questions with the help of a code. The method does not require any instalment or adjustment as students can use their own laptops, tablets, or smart phones. The respective results can be shown in real time, but it is possible to hide them until everyone finishes answering. Furthermore, there is no need for documentation or additional administration as the results are automatically saved by the webpage, and they can be downloaded later as well. The Mentimeter is an open-source code-based application facilitating the preparation of 13 types of questions.

The software helps teachers in making lessons interactive via surveying the opinions of students regarding a given question or issue. Moreover, it can also be used as a formative evaluation device. Another option is establishing a ranking order among the members of the class if they identify themselves by name before answering. Additionally, the system is suitable for preparing a traditional presentation and can help in the compilation of interactive word clouds too. Figure 2 shows the editing surface of the program. 

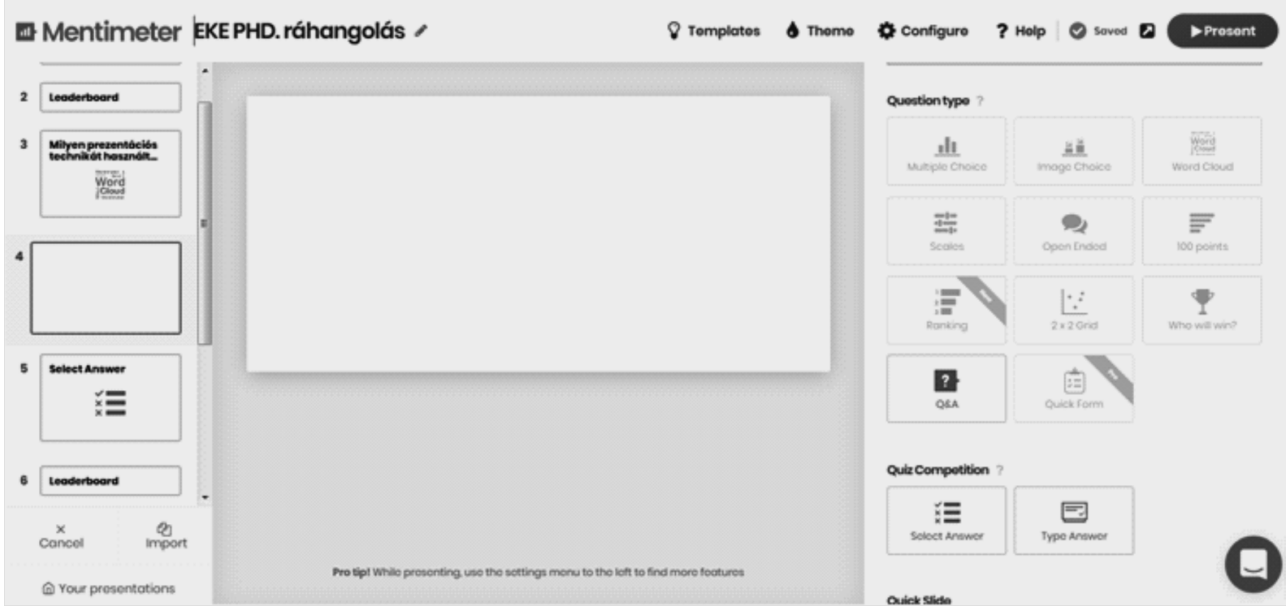

Source: author's screenshot

Figure 2. The editing surface of Mentimeter following entry

\section{Linoit (https://en.linoit.com)}

Linoit is a virtual wall to which virtual paper slips can be attached. Such slips could include videos, pictures, simple texts, or even LearningApps tasks. The wall can be shared with learners so that they can work on the given tasks at home. Furthermore, differentiated learning activities and anonymous user options are available as well. In addition, the wall facilitates gamification as students can select from assignments to be solved. The application also makes the collection of the ideas of learners and colleagues in a given topic and question possible. Students only need a smart device, and they can take notes on-line, and sharing can take place via $\mathrm{QR}$ codes or links.

The most frequent user options provided by Linoit are:

- Brainstorming

- Question bank

- On-line student portfolios

- Conceptual maps

- Exit ticket

The next figure shows the digital surface of Linoit. 


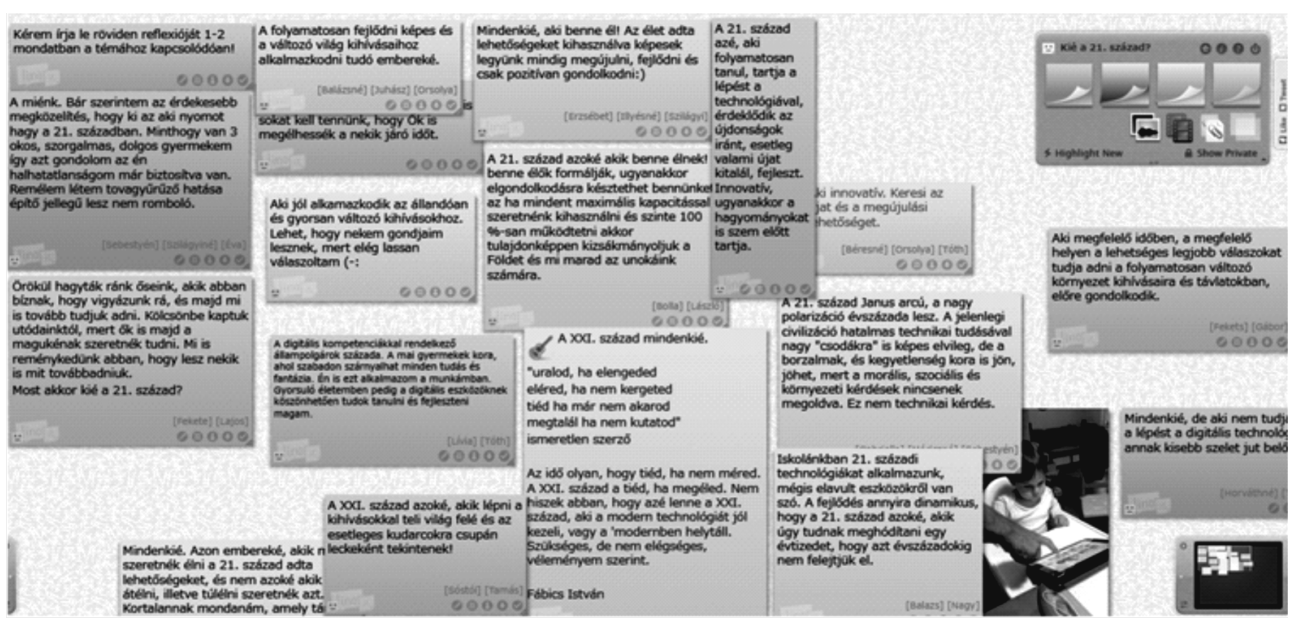

Source: author's screenshot

Figure 3. The editing surface of Linoit following entry

\section{Community Bookmarks}

These options allow the user to save the addresses of webpages into a list for the availability of contents he considers important in the future. Each component of the bookmark can be labelled with key terms facilitating a grouping effort. The bookmark collection receives a community role when we share them with others. Consequently, the shared bookmarks and the respective labels form a large, mutually usable set enabling the user to identify the websites marked by the given identical label or key term. Compared to the use of search engines, information acquisition can become more effective this way. At the same time, we can find users interested in similar topics. Therefore, it is recommended to follow or monitor such collections as it can help us in obtaining up-to-date information.

The use of bookmarks in cooperative learning: students and the teacher sharing their own bookmarks can help each other in obtaining information by using the resulting content during a project work.

- The use of bookmarks in collaborative learning: the teacher establishes a bookmark set of a given theme with the help of students, thereby constructing the reference register of a given theme. The labels help in the categorization of the specific sources.

- The bookmarks related to the given subject can be shared with the students, thereby establishing a reference knowledge base.

One such specific solution promoting community bookmarking services is Symbaloo. 


\section{Symbaloo (https://www.symbaloo.com)}

Symbaloo is a webpage for the collection of links facilitating the construction of individual learning routes. It is suitable for the creation of digital bookmarks regardless of the given search engine. One's favourite links can be found via any computer, and the links can be shared as well.

Links to frequently used or essential webpages or Web 2.0 applications should be built in a "digital tile" on the opening pages.

All favourite webpages are automatically synchronized with the smartphone or the tablet after downloading the Symbaloo application and registering.

It is very easy to operate, and favourite websites or applications can be added by a single click. The links can be grouped into a digital tile according to location, colour and/or pages, or themes. Its favourable appearance is coupled with an ability to create an attractive webmix or emphasizing links and topics. Students will enjoy the webmix to be used during projects or class work. Students can be provided with super-fast access to websites by sharing the link in e-mail or on social media surfaces. Thus, the chances of surfing to other pages, mistyping web addresses, or opening non-relevant pages can be minimized.

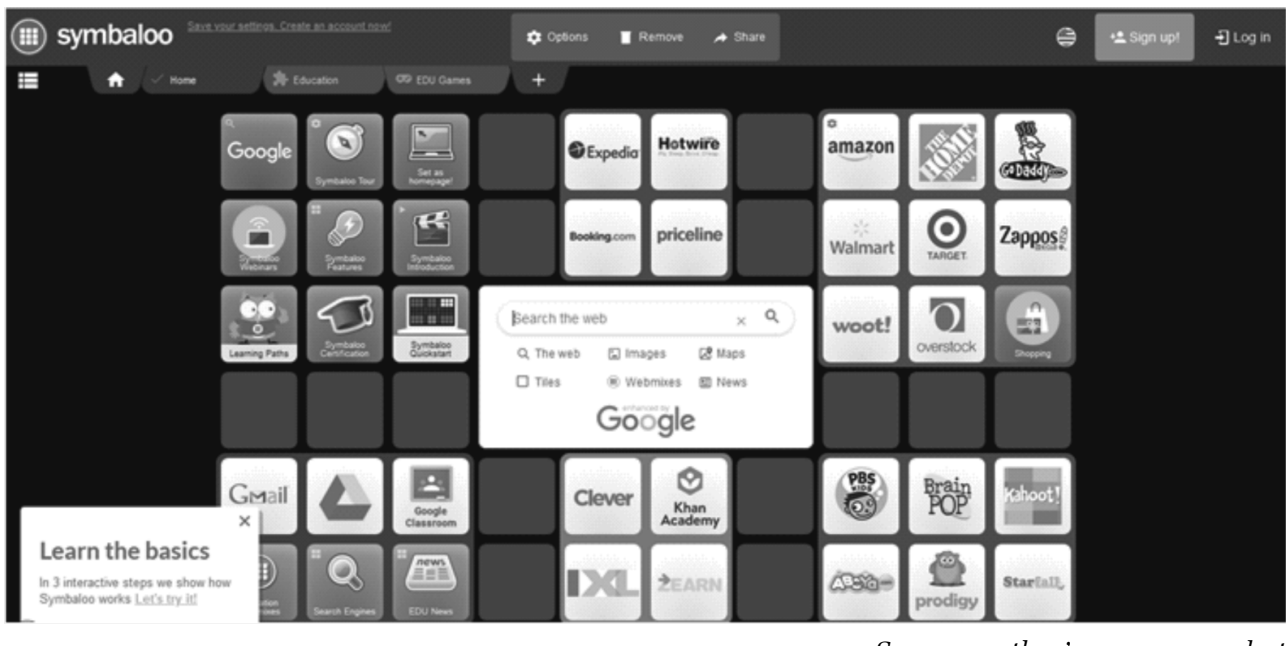

Figure 4. The editing surface of the Symbaloo program

\section{Kahoot! (https://kahoot.com)}

If we want to arrange a digital quiz or voting in a given class, the best method is Kahoot!. Its greatest advantage is that it can be used with any device regardless of platform. 
Students can use their own phones or tablets, the voting surface is available from the browser, and the program can be downloaded also as an application. According to students' feedback, Kahoot! and Plickers are considered simple to use, but the former one not only establishes the appropriateness of the answer but measures the speed of giving a response. The number of the questions is determined by the person who prepares the test, while pictures, figures, or videos can enliven the questions. Students providing fast and right answers are given the most points. The answers and points related to each question are saved on the teacher's website, and the related statistics can be saved, analysed, or used for summative evaluation.

Teachers can register, prepare, and start the game free of charge. The game is accessible via a "Game Pin" available through a webpage or application. Students are identified only by a nickname and can answer each question within a set time limit. In addition to one's own (private) questions, the question series can be shared with other users. Anyone can select or edit any publicly accessible quiz.

After the game, students can provide feedback concerning how they felt during the game or whether they learned anything new. Hence, it can function as an exit card. The next figure shows the editing surface of Kahoot!.

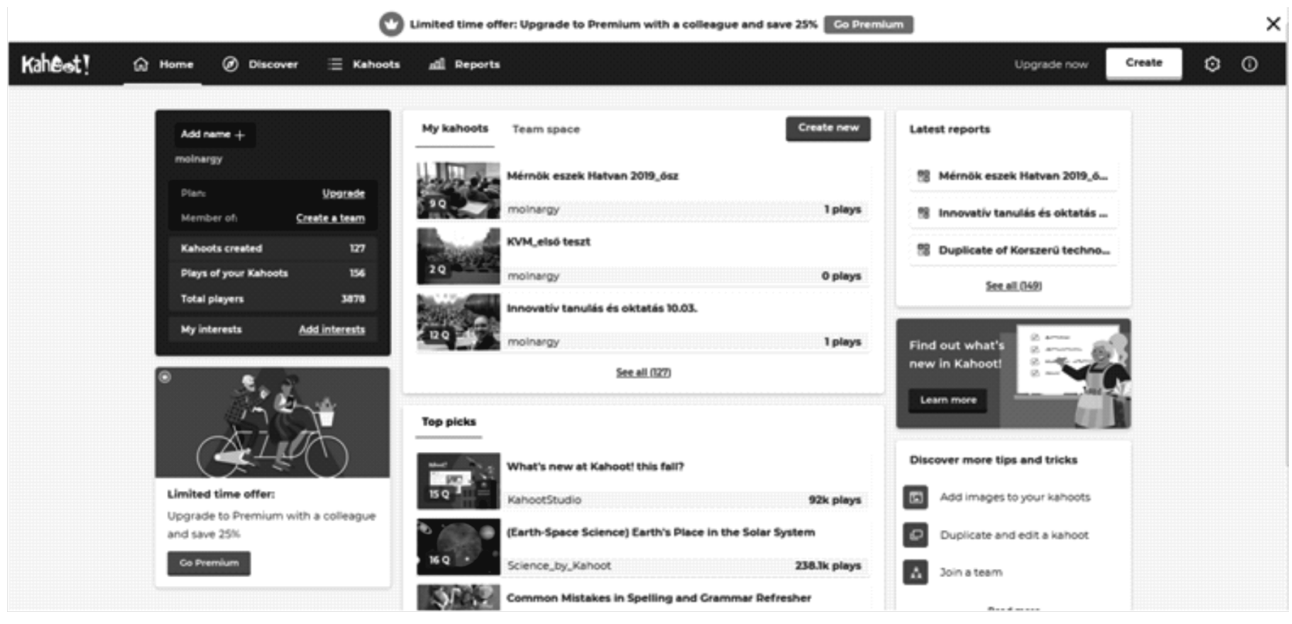

Source: author's own screenshot

Figure 5. The editing surface of Kahoot! after entry

\section{LearningApps (https://learningapps.org)}

LearningApps.org is a result of a joint research and development project of the Pedagogical College of Bern, the University of Mainz, and the College of Zittau/ Görlitz. It is a web surface suitable for the preparation of interactive educational support materials. After registration, users can create or share applications or 
learning cubes via the use of templates or patterns. As a result of the efforts of a master teacher workgroup, the program is available in Hungarian as well.

The "learning cubes" are basically the specific tasks that can be created by the users after filling the task templates, or moulds, with content. At the same time, there is the option of selecting from the learning cubes created by the other users, and the given learning cubes can be converted or transformed upon demand.

The webpage is easy to use and facilitates differentiated task assignment. Students can be invited into a virtual class where the learning cubes can be shared and completed. The given tasks presented by the learning cubes can be solved on an interactive board frontally or on the students' own devices independently. The program allows students to practice at home as well. Since the completed learning cubes are not considered self-contained, closed teaching units, they have to be embedded or integrated into a proper learning environment. Thus, a given type of learning cube can be used with other subjects in a variety of ways.

The program includes a multiplayer mode, and users can create a collection of tasks (Matrix). When preparing the collection, one's own exercises and those created by others can be used along with the option of including references. Such data can be integrated into our blog or website as in the case of any other application.

The most frequent assignment types include matching, arranging concepts into categories, establishing the chronological order or timeline, crossword puzzle, word search, and filling gaps in a text. Figure 6 illustrates the editing surface of the learning cubes.

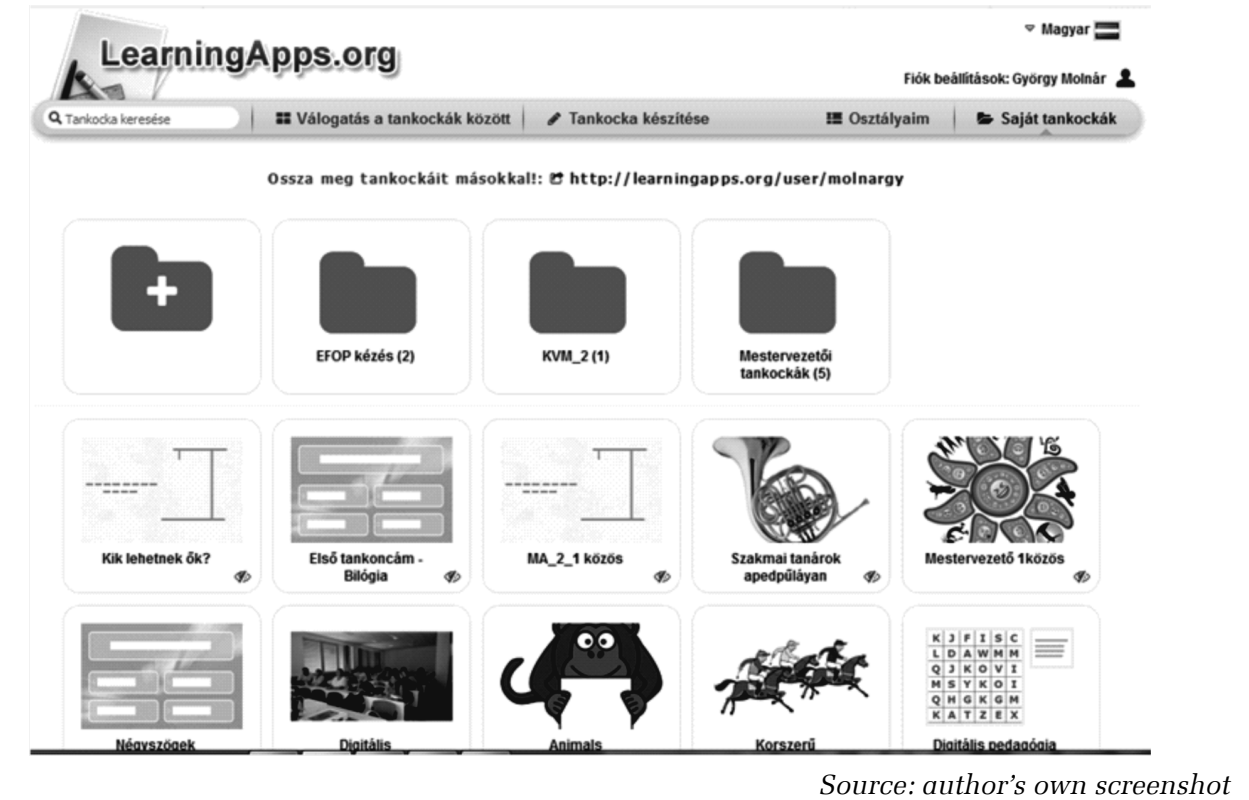

Figure 6. The editing surface of learning cubes after entry 


\section{Empirical, Inductive Research Related to the Present Theme}

Today's knowledge-based society requires experience-based learning and an environment which encourages students to explore and achieve results. Web 2.0 devices enabling students to systemize their knowledge while not closing it off from each other, thus making a collaborative effort in solving the given tasks, is an important context of our research. Accordingly, in the autumn of 2019, an on-line questionnaire-based inquiry investigated students' preliminary knowledge and familiarity with the previously described programs and the relevant using skills or proficiency levels. The random and simple sample yielding 197 valid responses included full-time students in the 18-22 age-group enrolled in business- and management-related programmes. The survey utilized the questionnaire form of Google Drive. Below, I will introduce the most significant results related to the abovementioned applications.

\section{Kahoot! (online test, voting system, evaluation...)}

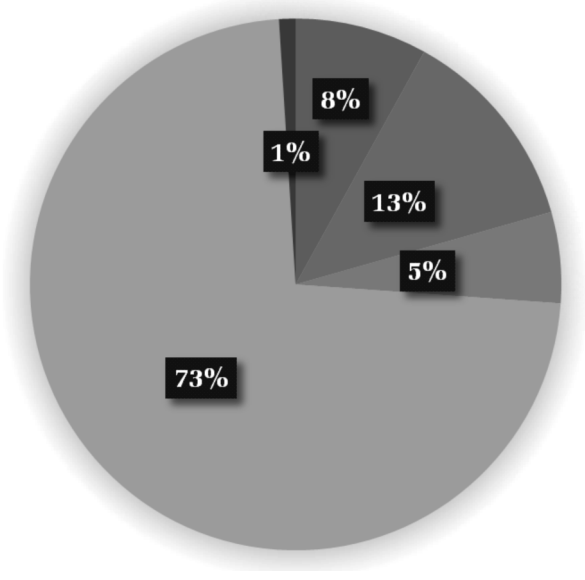

I have heard about it

I saw other teachers using it

I I use the program as part of my everyday teaching practice

I have registered and I have tried the program already

Source: author's own chart

Figure 7. The range of familiarity with and the use of Kahoot!

Figure 7 describes users' familiarity with Kahoot!. Accordingly, 73.1\% have already tried it out, $12.7 \%$ of the respondents saw other teachers using the program, and $7.6 \%$ have only heard about the application. 
Mentimeter (online presentation, test, voting system, evaluation...)

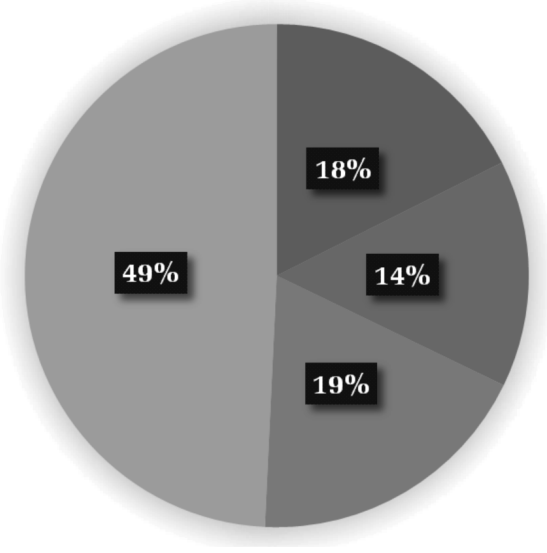

I have heard about it

I saw other teachers using it

I haven't heard about it

- I have registered and I have tried the program already

Source: author's own chart

Figure 8. The range of familiarity with and the use of Mentimeter

Figure 8 demonstrates that $49.7 \%$ of the respondents have used and already tried the program, $18.3 \%$ have never heard about it, $17.8 \%$ were familiar with it, and $14.2 \%$ saw other people using it.

\section{LearningApps (online digital task manager)}
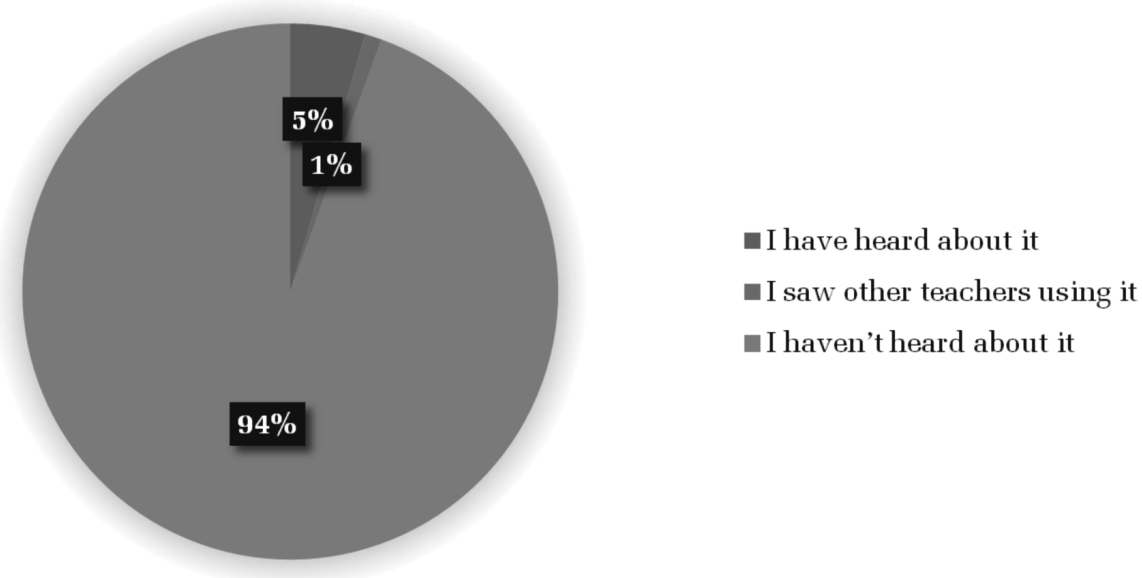

Source: author's own chart

Figure 9. The range of familiarity with and the use of LearningApps

Regarding the use of LearningApps or the learning cubes, $94.4 \%$ of the respondents have not heard about the program, $4.6 \%$ have heard about it, and $1 \%$ have already seen somebody using it. 


\title{
Plickers (Voting system with 1 teacher mobile phone)
}

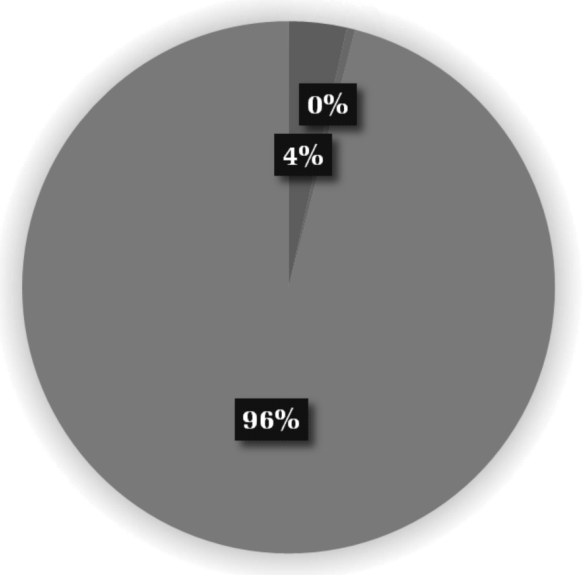

$$
\begin{aligned}
& \text { - I have heard about it } \\
& \text { I saw other teachers using it } \\
& \text { I haven't heard about it }
\end{aligned}
$$

Source: author's own chart

Figure 10. The range of familiarity with and the use of Plickers

The chart shows that $95.9 \%$ of the respondents have not heard about the program, 3.6\% have heard about it, and 1\% saw somebody using it.

\section{Padlet/Linoit (digital message board)}

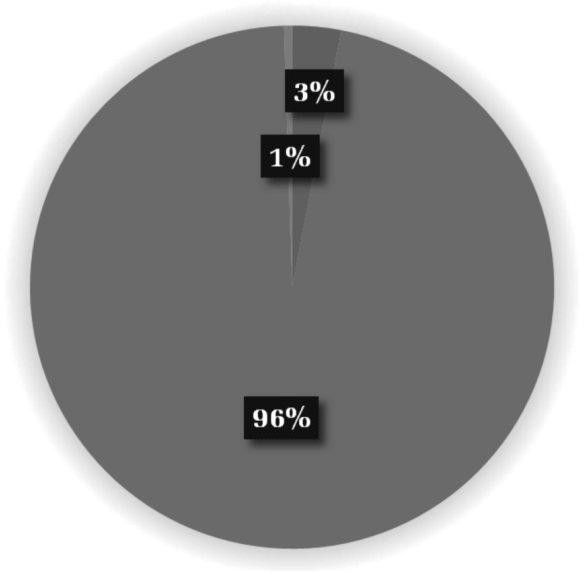

\author{
I have heard about it \\ I haven't heard about it \\ I have registered and I have \\ tried the program already
}

Source: author's own chart

Figure 11. The range of familiarity with and the use of Padlet/Linoit

As far as the program is concerned, $3 \%$ have heard about it, $96.4 \%$ had no knowledge about it whatsoever, and $1 \%$ have already registered for it. 


\title{
Symbaloo (own link collection - creator - systematizing, digital bookmark)
}

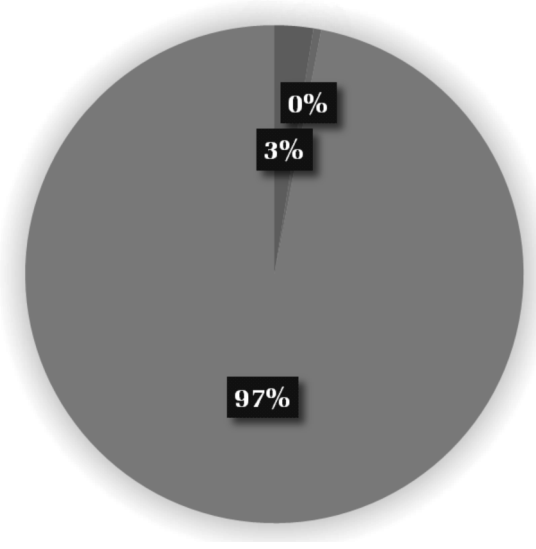

\author{
I have heard about it \\ - I saw other teachers using it \\ I haven't heard about it
}

Source: author's own chart

Figure 12. The range of familiarity with and the use of Symbaloo

The lack of familiarity was the greatest in the case of Symbaloo as $97 \%$ have never heard about it, only $2,5 \%$ were familiar with it, and merely $1 \%$ saw other people using it.

\section{Summary of Results}

Our study focused on ways of supporting the process of knowledge transmission and acquisition in the digitalized world and explored relevant student feedback with the help of digital tools. Our empirical survey assessing the respective demands concluded that even the younger generation is relatively unfamiliar with most of the interactive learning support systems, especially the Symbaloo, LearningApps, Linoit, and Plickers. Consequently, such programs and approaches should be integrated into the methodological arsenal of teachers. The emphasis on such modern approaches will naturally present a challenge for today's teachers while providing professional enhancement and enabling them to accommodate the needs of the new digital generation more effectively. 


\section{References}

Bodnár, É.-Sass, J. (2014). Kihívások: Változó tanulók - változó módszerek változó tanárszerepek. In: Tóth, P.-Ősz, R.-Várszegi, Á. (eds.), Pedagógusképzés - személyiségformálás, értékközvetítés, értékteremtés: IV. Trefort Ágoston Szakmai Tanárképzési Konferencia tanulmánykötet. Budapest: Trefort Ágoston Centre of Óbudai Egyetem, 183-196.

Hülber, L. (ed.). (2017). A digitális oktatási kultúra módszertana [Methodology of Digital Education Culture]. Eger: Eszterházy Károly Egyetem.

György, M.-Szüts, Z. (2016). What is the Worth of Digital Content and Online Curriculum for Students? Lessons from Survey Conducted at BME. In: SISY 2016, IEEE 14 ${ }^{\text {th }}$ International Symposium on Intelligent Systems and Informatics. Szabadka, Serbia, 29-31 August 2016, 245-250.

Prensky, M. (2001). Digital Natives, Digital Immigrants. On the Horizon 9(5): 1-6. (2012). From Digital Natives to Digital Wisdom: Hopeful Essays for 21 $1^{\text {st }}$-Century Learning. Los Angeles: Corwin Press.

Skills \& Learning, Bournemouth, Dorset, Poole, 2017. <https://www. skillsandlearningace.com/wp-content/uploads/2017/07/SE-Brochure-FinalProof.pdf> (accessed on: 3 November 2019).

Szúts, Z. (2014). Szingularitás előtt - papír és képernyő között [Before Singularity - Between Paper and Screen]. Korunk 3: 29-34. 